\title{
Anthropometric, cardiovascular and functional variables as indicators of health related physical fitness in university professors
}

\author{
Variáveis antropométricas, cardiovasculares e funcionais \\ como indicadores de aptidão física relacionada \\ à saúde em professores universitários
}

\author{
Osvaldo Costa Moreira ${ }^{[a]}$, Renata Aparecida Rodrigues de Oliveira ${ }^{[b]}$, \\ Cláudia Eliza Patrocínio de Oliveira ${ }^{[b]}$, Leonice Aparecida Doimo ${ }^{[\mathrm{b}]}$, \\ Paulo Roberto dos Santos Amorim ${ }^{[b]}$, João Carlos Bouzas Marins ${ }^{[b] *}$ \\ [a] Universidade Federal de Viçosa (UFV), Instituto de Ciências Biológicas e da Saúde, Florestal, MG, Brazil \\ [b] Universidade Federal de Viçosa (UFV), Departamento de Educação Física, Viçosa, MG, Brazil
}

\begin{abstract}
Objective: To verify the behavior of anthropometric, cardiovascular and functional variables as indicators of health-related physical fitness in university professors and perform a comparison of these variables between sexes. Materials and methods: We conducted an observational epidemiological cross-sectional study in 145 professors (45.86 \pm 9.7 years), 103 men (71.03\%), which were evaluated by measuring heart rate (HR) and systolic (SBP) and diastolic (DBP) pressure at rest, body weight, height, body mass index (BMI), body fat percentage (BF\%), handgrip strength (HGS), flexibility and cardiorespiratory fitness (CRF). We proceeded to the
\end{abstract}

* OCM: MSc, e-mail: osvaldo.moreira@ufv.br RARO: MSc, e-mail: renata.oliveira@ufv.br CEPO: MSc, e-mail: cpatrocinio@ufv.br LAD: PhD, e-mail: ladoimo@ufv.br PRSA: PhD, e-mail: pramorim@ufv.br JCBM: PhD, e-mail: jcbouzas@ufv.br 
descriptive analysis, Student t-test for comparison between sexes and multiple regression analysis to verify the association between the variables analyzed. It was adopted a significance level of $p<0.05$. Results: The sex affected all variables. Women had better levels of BMI, flexibility, SBP and DBP. The BF\% and CRF were associated with SBP and BMI in both sexes. Conclusion: The behavior of anthropometric, cardiovascular and functional variables indicated unsatisfactory values for flexibility, HGS and BMI, with the worst levels among men. Furthermore, the variables that showed better association with HRPF were BF\% and CRF.

Keywords: Health. Lifestyle. Aptitude tests. Adiposity. Anthropometry.

\section{Resumo}

Objetivo: Verificar o comportamento de variáveis antropométricas, cardiovasculares e funcionais como indicadores de aptidão física relacionada à saúde em professores universitários, bem como realizar a comparação dessas variáveis entre os sexos. Materiais e métodos: Realizou-se um estudo epidemiológico observacional de corte transversal em 145 professores (45,86 $\pm 9,7$ anos), sendo 103 homens (71,03\%), que foram avaliados, por meio de medidas de frequência cardíaca (FCR) e pressão arterial sistólica (PAS) e diastólica (PAD) de repouso, massa corporal, estatura, índice de massa corporal (IMC), percentual de gordura corporal (\%GC), força de preensão manual (FPM), flexibilidade e aptidão cardiorrespiratória (ACR). Procedeu-se à análise descritiva dos dados, teste t de Student para comparação entre sexos e análise de regressão múltipla para verificar a associação entre as variáveis analisadas. Adotou-se nível de significância de $p<0,05$. Resultados: 0 sexo influenciou todas as variáveis. As mulheres apresentaram níveis melhores de IMC, flexibilidade, PAS e PAD. O \%GC e a ACR associaram-se à PAS e ao IMC em ambos os sexos. Conclusão: O comportamento de variáveis antropométricas, cardiovasculares e funcionais indicou valores insatisfatórios para flexibilidade, FPM e IMC, com níveis piores nos homens. Além disso, as variáveis que melhor se associaram à AFRS foram o \%GC e a ACR.

Palavras-chave: Saúde. Estilo de vida. Testes de aptidão. Adiposidade. Antropometria.

\section{Introduction}

The health-related physical fitness (HRPF) can be understood as the capacity of an individual carry out his daily life activities with ease and less effort (1). The components of physical fitness related to reduced risk of morbidity and mortality, and thus, with health are: cardiorespiratory fitness, muscular strength, flexibility and body composition $(1,2)$.

Adequate levels of HRPF may promote reduction of chronic degenerative disorders, in addition to prevention, maintenance and improvement of the functional capacity (1). Because of this fact, investigations of the components that constitute it have attracted the interest of some research groups in Brazil $(3,4,5$, $6)$. These studies state that the behavior of the indicator variables of HRPF present distinct values between males and females and tend to show worsened levels as individuals get old. However, publications about HRPF in adults, especially of specific populations, such as university professors, are still little explored in the literature, since most publications only focus on isolated indicators, such as anthropometric variables or cardiovascular risk factors $(6,7,8)$.

Therefore, the development of investigations aimed to characterize the HRPF components in other population groups, such as university professors, besides adding information to the scientific literature on this issue, can optimize the application of material, financial and human resources, in order to contribute to the development and implementation of actions to promote a physically active lifestyle and to help in the improvement of functional capacity and performance in everyday and work activities in these individuals.

Based on the above, this study aimed to verify the behavior of anthropometric, cardiovascular and functional variables as indicators of health-related physical fitness in university professors as well as perform the comparison of these variables between the sexes. 


\section{Materials e methods}

We conducted an epidemiological cross-sectional study, in a population of university professors of the Federal University of Viçosa (UFV), regardless of gender, ethnicity and age.

The sample size was calculated according to the equation proposed by Lwanga and Lemeshow (9), so that, for probabilistic substantiation, a sample of 138 professors was necessary, considering the total number of teachers of the institution $(767$ professors) and a standard error of $5 \%$ with a $98 \%$ confidence interval.

After the approval by the Ethics Committee on human research of UFV (Of. Ref. No. 009/2009/ Ethics Committee), all professors of the institution were informed, and after performing a simple random draw, the drawn ones were invited to participate in this study, employing strategies by invitation letter and personal e-mail. Upon confirmation of interest in participating and fulfilled the Informed Consent, it was done a schedule for individualized assessment. Considering the possibility of losses and refusals, the sample size was increased in $20 \%$, seeking to assure that the minimum subjects to be part of the study was reached.

All assessments happened at the Human Performance Laboratory, at UFV Physical Education Department, in the morning, between $7 \mathrm{~h}$ and $9 \mathrm{~h}$ a.m., performed in a heated room (around $22{ }^{\circ} \mathrm{C}$ and $55 \%$ relative humidity) by an experienced assessor and prior trained for the routine of study, which followed standard procedure, consisting of: maintaining the evaluated at rest for measurement of resting parameters, anthropometry and measurement of physical fitness parameters, followed by development of individual reports for each evaluated. Before any measure, a pre-participation triage was done through the application of questionnaires RISKO (10) and PAR-Q (11), in order to preserve the physical integrity of the volunteers.

\section{Resting measures}

Resting measurements were performed in the morning, with the individual lying at supine decubitus position, after prior rest of, at least, five minutes. The resting heart rate (RHR) was obtained through a heart monitor (Polar, model F610) computing the lower heart rate obtained in the five-minute interval. Systolic blood pressure (SBP) and diastolic (DBP) were measured with the evaluated in the supine decubitus position using a mercury sphygmomanometer with a cuff standard for adult (Unilec ${ }^{\mathrm{TM}}$ ), properly calibrated. The measures were carried out according to criteria proposed by the Brazilian Society of Cardiology (12).

\section{Anthropometry}

The body mass of the subjects was obtained in a digital scale (Filizola) with accuracy of $0.05 \mathrm{~kg}$ and height was determined using a wall stadiometer $\left(\right.$ Sanny $\left.^{\mathrm{TM}}\right)$, with accuracy of $0.1 \mathrm{~cm}$. From this information it was determined the body mass index (BMI), classifying it according to the World Health Organization (WHO) (13).

As body adiposity indicator were measured the skinfolds triceps, suprailiac and thigh for women and pectoral, abdominal and thigh for men, taking as reference Jackson \& Pollock technique (14). These measurements were performed with skinfold caliper (Cescorf, model Top Tec, Brazil) with accuracy of 0.1 $\mathrm{mm}$ and constant pressure of $10 \mathrm{~g} / \mathrm{mm}^{2}$ in its opening. All measurements were made in rotational form and replicated three times, considering the median value. The anthropometric procedures met the criteria of the American College of Sports Medicine (15).

\section{Physical fitness tests}

As strength indicator parameter, it was used the hand grip test, which was performed using a mechanical dynamometer (Sammons Preston ${ }^{\mathrm{m}}$, model JAMAR). Three trials alternately were performed, computing the highest values of both hands. The classification table adopted was proposed by the Canadian Society for Exercise Physiology (15).

It was used the sit-and-reach test to assess the flexibility, which was conducted with a mat and Wells' standard bank (Sanny ${ }^{\mathrm{TM}}$ ). The classification table of levels of flexibility adopted was proposed in the Canadian Standardized Test Fitness (15). Both the strength test and the flexibility met the rules of the American College of Sports Medicine (15).

As an indicator parameter of cardiorespiratory fitness (CRF), it was used the submaximal treadmill 
test of single-stage proposed by Ebbeling et al. (16), which was performed by adopting the following procedure: three minutes of warm-up, which progressively increased in load and inclination; a single stage of four minutes with constant load and inclination; and three minutes of recovery with progressive decrease of inclination and speed.

\section{Statistical treatment}

All data obtained were stored and analyzed using the statistical softwares Sigma Stat for Windows version 2.03 and SPSS 17. The data analysis consisted of descriptive exploration of the variables studied. It was verified initially the normality of the variables using the Kolmogorov-Smirnov test. The Student t-test was used to comparison between sexes. The multiple regression analysis was used in order to verify the association between the values of indicator variables of HRPF analyzed. For all treatments, it was adopted a significance level of $\mathrm{p}<0.05$.

\section{Results}

This study assessed 145 professors, with a mean age of $45.86 \pm 9.72$ years, with 103 men $(71.03 \%)$ and 42 women $(28.97 \%)$, with $38.62 \%(n=56)$ of these individuals aged concentrated between 41 and 50 years. Table 1 shows the anthropometric and functional characteristics of professors assessed and the comparison of the physical fitness and health components according to sex.

When the sample studied is stratified by age and compared according to their age group, it was possible to notice an upward trend in BMI (41-50 years = $24.44 \pm 3.14 \mathrm{~kg} / \mathrm{m}^{2} ; 51$ to 60 years $=26.01 \pm 3.24$ $\mathrm{kg} / \mathrm{m}^{2}$; over 60 years $=27.83 \pm 6.96 \mathrm{~kg} / \mathrm{m}^{2}$ ) and SBP $(41-50$ years $=113.39 \pm 10.79 \mathrm{mmHg}, 51$ to 60 years $=$ $121.97 \pm 9.97 \mathrm{mmHg}$; over 60 years $=124.5 \pm 12.57$ $\mathrm{mmHg}$ ), especially after 60 years. Furthermore, it is observed decreased flexibility levels $(41-50$ years $=$ $24.57 \pm 10.49 \mathrm{~cm} ; 51$ to 60 years $=17.47 \pm 10.48 \mathrm{~cm}$; over 60 years $=9.2 \pm 10.79 \mathrm{~cm})$ and CRF $(41-50$ years = $43.06 \pm 6.71 \mathrm{ml} / \mathrm{kg} \cdot \mathrm{min}^{-1} ; 51$ to 60 years $=38.38 \pm$ $5.02 \mathrm{ml} / \mathrm{kg} \cdot \mathrm{min}^{-1}$; over 60 years $=34.58 \pm 2.34 \mathrm{ml} /$ kg. $\mathrm{min}^{-1}$ ), following the increase of age, especially after 50 years old.

Figure 1 shows the classification of the components of physical fitness, according to sex. Nevertheless, the Tables 2 and 3 show the relationship of physical fitness indicators $\mathrm{CRF}$ and \%BF, with health indicators SBP and BMI both in women and men. In men, flexibility also showed correlation with BMI.

\section{Discussion}

This study seeked to verify the behavior of anthropometric, cardiovascular and functional variables as indicators of health-related physical fitness and in university professors, as well as perform the comparison of these variables between the sexes.

Table 1 - Characterization and comparison of the physical fitness and health components of professors at UFV, according to sex

(To be continued)

\begin{tabular}{lccc}
\hline Variable & $\begin{array}{c}\text { Male }(\mathrm{n}=103) \\
\text { Mean } \pm \text { SD }\end{array}$ & $\begin{array}{c}\text { Female }(\mathrm{n}=42) \\
\text { Mean } \pm \text { SD }\end{array}$ & p value \\
\hline Age (years) & $46.90 \pm 9.82$ & $43.27 \pm 9.09$ & 0.042 \\
BM $(\mathrm{kg})$ & $77.56 \pm 11.97$ & $62.10 \pm 9.89$ & $<0.001$ \\
Estatura (m) & $1.74 \pm 0.07$ & $1.61 \pm 0.06$ & $<0.001$ \\
BMI $\left(\mathrm{kg} / \mathrm{m}^{2}\right)$ & $25.57 \pm 3.54$ & $24.11 \pm 3.65$ & 0.027 \\
\%BF & $22.58 \pm 6.05$ & $31.37 \pm 6.83$ & $<0.001$ \\
CRF $\left(\mathrm{ml} / \mathrm{Kg} \cdot \mathrm{min}^{-1}\right)$ & $43.34 \pm 6.12$ & $35.85 \pm 5.98$ & $<0.001$ \\
Flexibility (cm) & $18.38 \pm 10.12$ & $27.40 \pm 10.66$ & $<0.001$ \\
HGS (kgf) & $100.68 \pm 16.03$ & $60.45 \pm 11.71$ & $<0.001$
\end{tabular}


Table 1 - Characterization and comparison of the physical fitness and health components of professors at UFV, according to sex

(Conclusion)

\begin{tabular}{lccc}
\hline Variable & $\begin{array}{c}\text { Male }(\mathrm{n}=\mathbf{1 0 3} \\
\text { Mean } \pm \text { SD }\end{array}$ & $\begin{array}{c}\text { Female }(\mathrm{n}=42) \\
\text { Mean } \pm \text { SD }\end{array}$ & p value \\
\hline RHR & $67.62 \pm 8.91$ & $71.07 \pm 7.12$ & 0.027 \\
SBP $(\mathrm{mmHg})$ & $118.79 \pm 10.01$ & $111.67 \pm 12.28$ & $<0.001$ \\
DBP $(\mathrm{mmHg})$ & $78.64 \pm 7.80$ & $74.88 \pm 8.94$ & 0.013 \\
\hline
\end{tabular}

Note: $\mathrm{BM}=$ body mass; $\mathrm{BMI}=$ body mass index; \%BF = body fat percentage; $\mathrm{HGS}=$ hand grip strength; $\mathrm{CRF}=$ cardiorespiratory fitness; $\mathrm{RHR}=$ resting heart rate; $\mathrm{SBP}=$ systolic blood pressure; $\mathrm{DBP}=$ diastolic blood pressure.

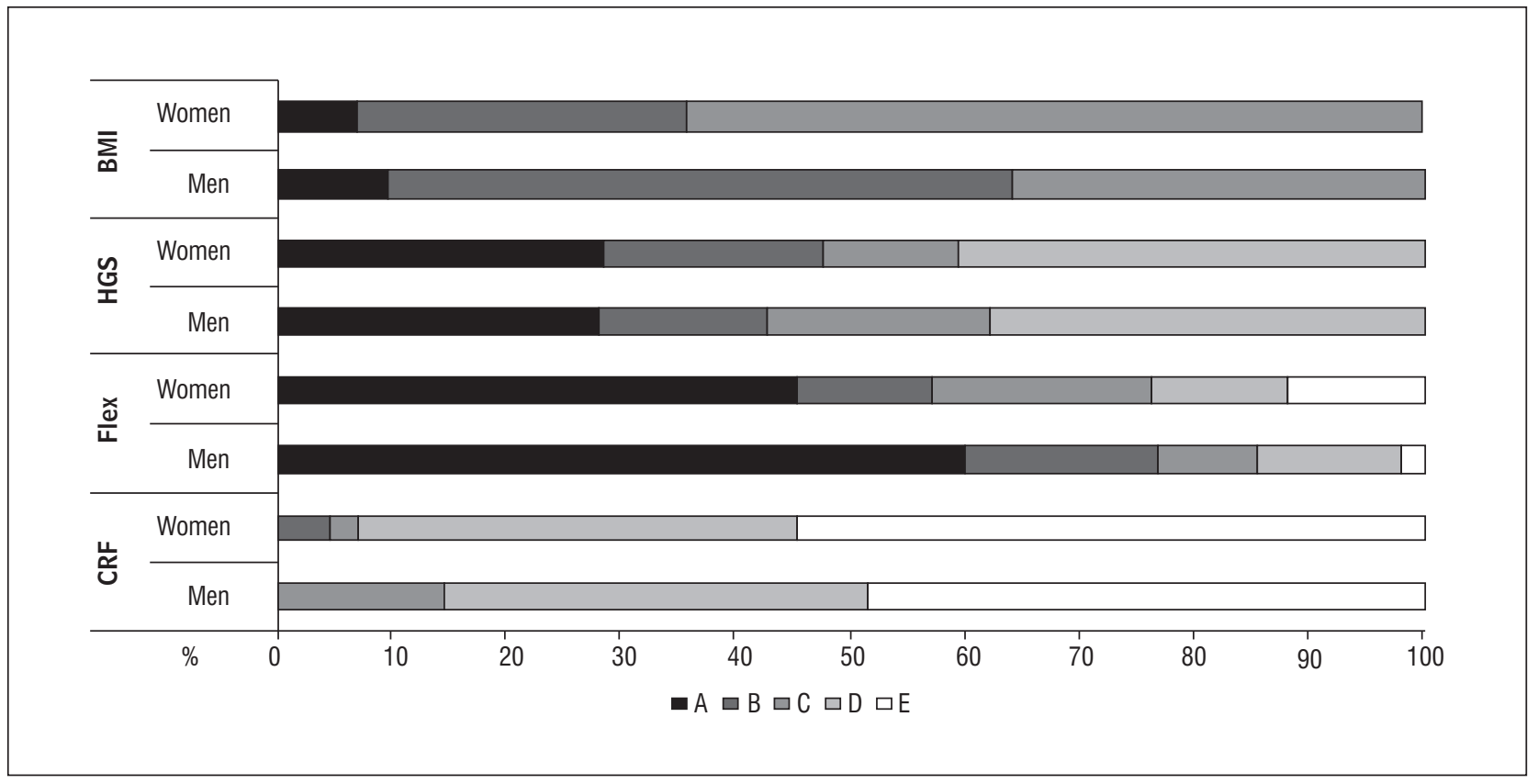

Figure 1 - Classification of physical fitness components according to sex

Note: $\mathrm{BMl}: \mathrm{A}=$ obesity; $\mathrm{B}=$ overweight; $\mathrm{C}=$ eutrophic; $\mathrm{D}=$ low weight; $\mathrm{HGS}$ : $\mathrm{A}=$ well below the mean; $\mathrm{B}=$ below the mean; $\mathrm{C}=$ mean;

$D=$ above the mean; $E=$ well above the mean; Flex: $A=$ well below the mean; $B=$ below the mean; $C=$ mean; $D=$ above the mean;

$\mathrm{E}=$ well above the mean; $\mathrm{CRF}: \mathrm{A}=$ very weak; $\mathrm{B}=$ weak; $\mathrm{C}=$ regular; $\mathrm{D}=$ good; $\mathrm{E}=$ excellent. $\mathrm{CRF}=$ cardiorespiratory fitness;

FLEX = flexibility; HGS $=$ hand grip strength; $\mathrm{BMI}=$ body mass index .

Table 2 - Relationship between indicator variables of physical fitness and health in the women assessed

(To be continued)

\begin{tabular}{|c|c|c|c|c|c|c|c|}
\hline & CRF & FLEX & HGS & $\% B F$ & $\mathbf{R}^{2}$ & $\begin{array}{c}\text { Standardized } \\
\text { coefficient }\end{array}$ & $\mathrm{p}$-value \\
\hline RHR & $\begin{array}{l}r=-0.12 \\
p=0.47\end{array}$ & $\begin{array}{l}r=-0.002 \\
p=0.49\end{array}$ & $\begin{array}{l}r=0.15 \\
p=0.18\end{array}$ & $\begin{array}{l}r=0.13 \\
p=0.18\end{array}$ & 0.05 & - & 0.746 \\
\hline SBP & $\begin{array}{l}r=-0.31 \\
p=0.02^{a}\end{array}$ & $\begin{array}{l}r=0.17 \\
p=0.14\end{array}$ & $\begin{array}{l}r=0.2 \\
p=0.1\end{array}$ & $\begin{array}{l}r=0.48 \\
p=0.001^{b}\end{array}$ & 0.37 & $\begin{array}{c}\text { a } 33 \% \\
\text { в } 47.7 \%\end{array}$ & 0.001 \\
\hline DPB & $\begin{array}{l}r=-0.13 \\
p=0.2\end{array}$ & $\begin{array}{l}r=0.08 \\
p=0.31\end{array}$ & $\begin{array}{l}r=0.2 \\
p=0.1\end{array}$ & $\begin{array}{l}r=0.32 \\
p=0.20\end{array}$ & 0.15 & - & 0.184 \\
\hline
\end{tabular}


Table 2 - Relationship between indicator variables of physical fitness and health in the women assessed

(Conclusion)

\begin{tabular}{|c|c|c|c|c|c|c|c|}
\hline & CRF & FLEX & HGS & $\% B F$ & $\mathbf{R}^{2}$ & $\begin{array}{c}\text { Standardized } \\
\text { coefficient }\end{array}$ & p-value \\
\hline BMI & $\begin{array}{l}r=-0.05 \\
p=0.39\end{array}$ & $\begin{array}{l}r=-0.05 \\
p=0.37\end{array}$ & $\begin{array}{l}r=0.18 \\
p=0.13\end{array}$ & $\begin{array}{l}r=0.84 \\
p<0.001 c\end{array}$ & 0.72 & c 83\% & $<0.001$ \\
\hline
\end{tabular}

Note: ${ }^{a}$ standardized coefficient of the relation between CRF and SBP; b standardized coefficient of the relation between \%BF e SBP; ${ }^{c}$ standardized coefficient of the relation between \%BF and BMI. CRF = cardiorespiratory fitness; FLEX = flexibility; HGS = hand grip strength; $\mathrm{BMI}=$ body mass index; \%BF = body fat percentage; $\mathrm{RHR}=$ resting heart rate; $\mathrm{SBP}=$ systolic blood pressure; $\mathrm{DBP}=$ diastolic blood pressure.

Table 3 - Relationship between indicator variables of physical fitness and health in the men assessed

\begin{tabular}{|c|c|c|c|c|c|c|c|}
\hline & CRF & FLEX & HGS & \%BF & $\mathbf{R}^{2}$ & $\begin{array}{c}\text { Standardized } \\
\text { coefficient }\end{array}$ & $\mathrm{p}$-value \\
\hline RHR & $\begin{array}{l}r=-0.23 \\
p=0.01\end{array}$ & $\begin{array}{l}r=-0.09 \\
p=0.19\end{array}$ & $\begin{array}{l}r=-0.11 \\
p=0.13\end{array}$ & $\begin{array}{l}r=0.16 \\
p=0.05\end{array}$ & 0.06 & - & 0.18 \\
\hline SBP & $\begin{array}{l}r=-0.24 \\
p=0.007^{a}\end{array}$ & $\begin{array}{l}r=-0.03 \\
p=0.37\end{array}$ & $\begin{array}{l}r=-0.13 \\
p=0.09\end{array}$ & $\begin{array}{l}r=0.42 \\
p<0.001\end{array}$ & 0.2 & $\begin{array}{l}\text { a } 15 \% \\
\text { в } 42.5 \%\end{array}$ & $<0.001$ \\
\hline DBP & $\begin{array}{l}r=-0.01 \\
p=0.16\end{array}$ & $\begin{array}{l}r=0.08 \\
p=0.22\end{array}$ & $\begin{array}{l}r=-0.03 \\
p=0.39\end{array}$ & $\begin{array}{l}r=0.12 \\
p=0.11\end{array}$ & 0.03 & - & 0.5 \\
\hline BMI & $\begin{array}{l}r=-0.19 \\
p=0.03 c\end{array}$ & $\begin{array}{l}r=-0.006 \\
p=0.48\end{array}$ & $\begin{array}{l}r=-0.22 \\
p=0.01^{d}\end{array}$ & $\begin{array}{l}r=0.75 \\
p<0.001\end{array}$ & 0.585 & $\begin{array}{c}\text { c } 1.5 \% \\
\text { d } 14.5 \% \\
\text { e } 83.1 \%\end{array}$ & $<0.001$ \\
\hline
\end{tabular}

Note: a standardized coefficient of the relation between CRF and SBP; b standardized coefficient of the relation between \%BF e SBP; c standardized coefficient of the relation between CRF and BMI; ${ }^{d}$ standardized coefficient of the relation between HGS e BMI; ${ }^{\text {e }}$ standardized coefficient of the relation between \%BF and BMI. CRF = cardiorespiratory fitness; FLEX = flexibility; $\mathrm{HGS}=$ hand grip strength; $\mathrm{BMI}=$ body mass index; \%BF = body fat percentage; RHR = resting heart rate; SBP = systolic blood pressure; DBP = diastolic blood pressure.

Therefore, it was found that men presented a higher absolute value of BMI, when compared to women. Similar data were described by Oliveira et al. (6) in university servants and by the Brazilian Society of Cardiology (8), in Brazilian adults. Besides, $64.08 \%$ of men and $35.71 \%$ of women presented classification values considered insufficient, i.e., BMI levels above $24.49 \mathrm{~kg} / \mathrm{m}^{2}$. Similar values were found in the study called "Hearts of Brazil" (8), which found 58.9\% of men and $57 \%$ of women with BMI inappropriate. The data from this study indicate that, university professors assume a high prevalence of overweight and obesity, a factor that may act as a mechanism for triggering a series of physical and physiological impairments.

It was observed an upward trend in BMI, from the age of 60 , similar to that described by Chumlea et al. (17) and Ortega-Alonso et al. (18). This is due to genetic changes that occur together with the aging process, responding for $58 \%$ of these changes in men and $64 \%$ in women (19). Furthermore, the decrease in physical activity levels (1) and dietary changes (20), may also negatively impact the BMI, promoting the increase of its values and, consequently, the cardiovascular risk.

Whereas the increase in BMI is related to the increased incidence of cardiovascular diseases, hypertension, diabetes, dyslipidemia, and other chronic diseases (17), it is believed that this factor is exposing professors to higher metabolic risk, as they get older. Since this is an older group, this finding shows the importance of actions of control and reduction of BMI, in order that this factor does not result, in future, in the genesis of chronic-degenerative diseases. 
Despite displaying higher values for BMI, men had a lower \%BF compared to women. Similar behavior for body composition were reported by Moreira et al. (21) in beginners in weight training gyms, where men had lower \%BF and higher BMI, when compared to women; and by Oliveira et al. (6), in university servants, in which women had lower BMI than men, however, higher concentrations of abdominal fat. A possible explanation for the higher BMI and lower BF\% in men, may be in the fact that they have greater component of lean body mass, giving them these higher body mass and impacting on BMI (22).

It is noticed that the variable BMI showed relationship with \%BF, both in women (Table 2), and in men (Table 3). The increase of $\% B F$, seems to be the most important factor for the increase of BMI, as it seems to explain $83.1 \%$ of the increase in men and $83 \%$ in women. In this sense, Kulkarni et al. (23) reported that the increase in body fat is strongly related to the increased BMI, concluding that body composition is closely associated with the work activity.

Additionally, the excess of body fat is a predisposing factor for hypertension, as observed in tables 2 and 3 , a possible explanation is the fact that there is a positive correlation between blood pressure and circulating angiotensinogen levels, and since the adipose tissue is an important source of extra-hepatic production of this substance, it is stated that subjects with high \%BF are inclined to an increased production of angiotensinogen and, thereby, increase of pressure levels (24).

Thus, the adoption of measures that result in reduction of \%BF of professors, such as participation in a regular exercise program and/or a nutritional guidance program, may have beneficial effects both in reducing the prevalence of hypertension, and in reducing the incidence of overweight and obesity, allowing the reduction of comorbidities associated to these diseases.

As described in the results, SBP and DBP values showed higher values for men than women, although the mean values for both sexes fit in the normal classification. Similar results were reported in studies of Oliveira et al. (6) and Moreira et al. (21). Although, the SBP showed a trend to follow the age increasing (25), fact that may be due to the triggering of the physiological changes proper of the aging process, which make the subjects more likely to develop hypertension as they get old $(9,25)$.
This behavior in the studied group may indicate that hypertension, can become an institutional health problem within a few years. Thus, measures must be adopted to promote the maintenance and/or improvement of HRPF and pressure levels, such as the insertion of physical exercises for professors community, since this practice is recommended to patients with hypertension as an option of treatment to reduce pressure levels in hypertensive and normotensive individuals $(9,26)$.

Another variable that showed downward trend with increasing age was the CRF, which may be explained by reductions in the supply of muscle oxygen, mainly due to reduced cardiac output, which plays an important role in reducing the CRF until middle age (27). Moreover, there is a decline in the oxidative capacity of skeletal muscle with aging, due to mitochondrial dysfunction that seems to play a particularly important role in reducing the CRF in the third age (27). Thus, the decline in CRF with age can generate a facilitating condition for cardiovascular impairments and increased blood pressure. This suggests the need to implement aerobic training, in order to maintain and/or increase the CRF and, consequently, the reduction of risk of cardiovascular accidents in the individuals assessed.

Although it is considered the most important component of physical fitness because of its strong association with the development of chronic-degenerative diseases (2), in this study, the CRF showed a discreet relationship with SBP, both in men and women, and with BMI in men. Similarly, Song et al. (28) found relationship between increased CRF and reduction in pressure levels, and improvement of the body composition in Korean businessmen who have undergone to a general check-up health in 2007. These data indicate that an exercise program that promotes increased aerobic capacity of the UFV professors, can beneficially impact the levels of blood pressure and body mass of these individuals, and thereby, minimize the risk of development of diseases, particularly cardiovascular diseases (1).

As well as the CRF and SBP, the flexibility showed a downward trend as the age increases, especially from the age of 50. This behavior is considered normal, according to Araújo (29), which can result in decreased health and quality of life of this population segment. It should be noted that this element of HRPF was considered the worst performance when 
analyzing the percentage of the population assessed, since $60.19 \%$ of men and $45.24 \%$ of women met the classification "well below average".

Values close to those found in this study were reported by Silva and Juvêncio (30), who used the same procedures for collecting such data in civil servants at UFV, with $60.72 \%$ in men and $72.22 \%$ women, for frequency of low physical fitness in relation to levels of flexibility, thus indicating that there is a similarity of results and enhancing the handicap in the levels of flexibility in this population amount.

The trunk anterior flexibility is an important component of clinical exams and physical fitness used as indicative of vertebral function. In this sense, lower levels of flexibility may be associated with a variety of musculoskeletal problems such as low back pain, which is one of the major causes of absence from work (31). Thus, the maintenance of adequate levels of flexibility can act as a protective factor against the appearance of the motor system diseases, being a strategy to be considered when developing actions of promotion of health and prevention of musculoskeletal diseases.

The HGS values of the professors showed that $42.72 \%$ of men and $47.62 \%$ of women are classified as "below the mean" or "well below the mean" (Figure 1). Similarly, Silva and Juvêncio (30) found frequency of unsatisfactory levels for HGS of $42.86 \%$ and $33.33 \%$ respectively for men and women. The HGS serves as an indicator of upper limbs strength, which is related to a series of activities of daily life that require some level of force, for example, sustain, hold or pull a heavy object, so it is recommended its assessment.

Despite of presenting some limitations, such as lack of information about the nutritional habits of the population studied, the difficulty of comparison with other studies in similar population segment, no execution of maximal tests and the impossibility of using a gas analyzer to determine the CRF, the results of this study point to the need to work towards the maintenance and improvement of HRPF indicators, thus outlining the actions to be developed in the institution as a form of promotion of health for professors.

Moreover, the results obtained in this study, added to the results of other studies that have been developed and are in progress with professors and servants of technical staff at UFV, it is intended to provide information on the health status of these individuals in order to subsidizing the implementation of an institutional health policy, involving both specific actions such as the prevention of risk factors campaigns, and the implementation of a health promotion program, which should be guided in multidisciplinary work and has as scientific basis on the studies performed in this population amount.

\section{Conclusion}

The results of this study indicate that, the professors presented unsatisfactory values of HRPF, for the variables: flexibility, hand grip strength and BMI, being found worse classification levels in males. Moreover, the indicator variables of physical fitness that showed better relationship with health indicators were the body fat percentage and cardiorespiratory fitness.

The information obtained may provide a starting point for the development and insertion of health promotion policies, since they point the indicators of health-related physical fitness that deserve more attention, thus serving, to outline future investigations, or even intervention actions in order to promote the prevention, maintenance and/or improvement of health levels and quality of life of UFV professors.

\section{Reference}

1. Haskell WL, Lee IM, Pate RR, Powell KE, Blair SN, Franklin BA, et al. Physical activity and public health: updated recommendation for adults from the American College of Sports Medicine and the American Heart Association. Circulation. 2007;116(9):1081-93.

2. Jorgensen T, Andersen LB, Froberg K, Maeder U, Smith LVH, Aadahl M. Position statement: testing physical condition in a population - how good are the methods? Eur J Sport Sci. 2009;9(5):257-67.

3. Dórea V, Ronque ERV, Cyrino ES, Serassuelo Junior H, Gobbo LA, et al. aptidão física relacionada à saúde em escolares de Jequié, BA, Brasil. Rev Bras Med Esporte. 2008;14(6):494-9.

4. Michelin E, Coelho CF, Burini RC. Efeito de um mês de destreinamento sobre a aptidão física relacionada à saúde em programa de mudança de estilo de vida. Rev Bras Med Esporte. 2008;14(3):192-6. 
5. Geraldes AAR, Oliveira ARM, Albuquerque RB, Carvalho JM, Farinatti PTV. A força de preensão manual é boa preditora do desempenho funcional de idosos frágeis: um estudo correlacional múltiplo. Rev Bras Med Esporte. 2008;14(1):12-16.

6. Oliveira RAR, Moreira OC, Andrade Neto F, Amorim W, Costa EG, Marins JCB. Prevalência de sobrepeso e obesidade em professores da Universidade Federal de Viçosa. Fisioter Mov. 2011;24(4):603-12.

7. Oliveira RAR, Moreira OC, Lopes PRNR, Amorim W, Breguez MS, Marins JCB. Variáveis bioquímicas, antropométricas e pressóricas como indicadores de risco cardiovasculares em servidores públicos. Fisioter Mov. 2013;26(2):367-77.

8. Sociedade Brasileira de Cardiologia. Atlas Corações do Brasil. São Paulo: SBC; 2005.

9. Lwanga SK, Lemeshow S. Sample size determination in health studies: a practical manual. Geneva: World Health Organization; 1991.

10. Michigan Heart Association. Risko. Lancet. 1973; 2(7823):243-4.

11. Chisholm DM, Collis ML, Kulak LL, Davenport W, Gruber N. Physical activity readiness. Br Col Med J. 1975; 17:375-8.

12. Sociedade Brasileira de Cardiologia. V Diretrizes brasileiras de hipertensão arterial. Arq Bras Cardiol. 2007;89(3):e24-e79.

13. National Institutes of Health. Clinical Guidelines on the Identification, Evaluation, and Treatment of Overweight and Obesity in Adults - The Evidence Report. National Institutes of Health. Obes Res.1998;6(Suppl 2): 51S-209S.

14. Jackson AS, Pollock ML. Generalized equations for predicting body density of men. Br J Nutrition. 1978; 40(3):497-504.

15. American College of Sports Medicine. Manual do ACSM para avaliação da aptidão física relacionada à saúde. Rio de Janeiro: Guanabara Koogan; 2006.

16. Ebbeling CB, Ward A, Puleo EM, Widrick J, Rippe JM. Development of a single-stage submaximal treadmill walking test. Med Sci Sports Exerc. 1991;23(8):966-73.
17. Chumlea WC, Choh A, Lee M, Towne B, Sherwood RJ, Duren D, et al. The first seriatim study into old age for weight, stature and BMI: the Fels Longitudinal Study. J Nutr Health Aging. 2009;13(1):3-5.

18. Ortega-Alonso A, Sipilä S, Kujala UM, Kaprio J, Rantanen T. Genetic influences on change in BMI from middle to old age: a 29-year follow-up study of twin sisters. Behav Genet. 2009;39(2):154-64.

19. Hjelmborg JV, Fagnani C, Silventoinen K, McGue M, Korkeila M, Christensen K, et al. Genetic influences on growth traits of BMI: a longitudinal study of adult twins. Obesity (Silver Spring). 2008;16(4):847-52.

20. Savoca MR, Arcury TA, Leng X, Bell RA, Chen H, Anderson A, et al. The diet quality of rural older adults in the South as measured by healthy eating index-2005 varies by ethnicity. J Am Diet Assoc. 2009; 109(12):2063-7.

21. Moreira OC, Oliveira RAR, Latkin CT, Oliveira CEP. Risco cardiovascular de ingressantes em academia de musculação. Rev Bras Prescr Fisiol Exerc. 2012;6(36):604-11.

22. van Geel TA, Geusens PP, Winkens B, Sels JP, Dinant GJ. Measures of bioavailable serum testosterone and estradiol and their relationships with muscle mass, muscle strength and bone mineral density in postmenopausal women: a cross-sectional study. Eur J Endocrinol. 2009;160(4):681-7.

23. Kulkarni B, Shatrugna V, Nagalla B, Rani KU. Regional body composition of Indian women from a low-income group and its association with anthropometric indices and reproductive events. Ann Nutr Metab. 2010;56(3):182-9.

24. Einstein FH, Atzmon G, Yang XM, Ma XH, Rincon M, Rudin E, et al. Differential responses of visceral and subcutaneous fat depots to nutrients. Diabetes. 2005; 54(3):672-8.

25. Souza ARA, Costa A, Nakamura D, Mocheti LN, Stevanato Filho PR, Ovando LA. Um estudo sobre hipertensão arterial sistêmica na cidade de Campo Grande, MS. Arq Bras Cardiol. 2007;88(4):441-6.

26. Amorim PRS, Moura BP, Moreira OC, Marins JCB. Efeito hipotensor de uma sessão de exercícios aquáticos: variabilidade e reprodutibilidade. R Bras Ci e Mov. 2009;17(2):1-20. 
27. Betik AC, Hepple RT. Determinants of VO2 max decline with aging: an integrated perspective. Appl Physiol Nutr Metab. 2008;33(1):130-40.

28. Song YK, Lee KK, Kim HR, Koo JW. Job demand and cardiovascular disease risk factor in white-collar workers. Ind Health. 2010;48(1):12-7.

29. Araújo CGS. Avaliação da flexibilidade: valores normativos do flexiteste dos 5 aos 91 anos de idade. Arq Bras Cardiol. 2008;90(4):280-7.

30. Silva CD, Juvêncio JF. Diagnóstico da aptidão física relacionada à saúde em trabalhadores de escritório da Universidade Federal de Viçosa. Rev Bras Cineantropom Desempenho Hum. 2004;6(1):63-71.
31. Coeuret-Pellicer M, Descatha A, Leclerc A, Zins M. Are tall people at higher risk of low back pain surgery? A discussion on the results of a multipurpose cohort. Arthritis Care Res (Hoboken). 2010; 62(1):125-7.

Received: 05/16/2014

Recebido: 16/05/2014

Approved: 04/07/2015

Aprovado: 07/04/2015 